\title{
Freud, Sullivan, Mitchell, Bion and the Multiple Voices of International Psychoanalysis
}

di Marco Conci

INTERNATIONAL BOOKS, NeW York, 2019

Freud, Sullivan, Mitchell, Bion, and the Multple Voices of International Psychoanalysis è un'opera imponente che raccoglie in 735 pagine un complesso intreccio di storia della psicoanalisi e storie di psicoanalisti. Una lettura per pochi, sembrerebbe. Ma non è così. Si tratta di un'antologia di testi - pubblicati tra il 1992 e il 2016 con l'eccezione di un lavoro inedito su 'Mitchel in Italia' - che si leggono un po' come si può guardare una serie TV che appassiona. 'Episodio' dopo 'episodio', l'architettura dei capitoli va a comporre un lungometraggio avvincente che si dipana dal giovane Freud fino ai giorni nostri. Cercherò dunque di tratteggiare qualche elemento saliente di questa opera senza fare troppi spoiler per lasciare spazio all'esperienza diretta del lettore/spettatore.

Innanzitutto due parole sull'autore. Marco Conci è medico, psichiatra, membro sia della Società Psicoanalitica Italiana sia della Deutsche Psychoanalytische Gesellschaft (entrambe componenti dell'International Psychoanalytic Association), ha pubblicato oltre 100 lavori indicizzati su Pep-Web ed è Co-Editor-in-Chief dell'International Forum of Psychoanalysis, Ed è proprio dalla biografia dell'autore che bisogna partire per entrare nella prospettiva di questo libro. Giusto alcuni flash: l'Alto Adige/Südtirol della sua infanzia, l'esperienza adolescenziale a New York, il suo lavoro successivo a Trento e a Monaco come psicoanalista in uno studio accreditato al sistema sanitario nazionale. Ma è soprattutto una sorta di terra senza frontiere quella che sembra delinearsi dai tanti viaggi e dalla fitta rete di scambi con studiosi internazionali. Questa peraltro è anche una sorta

\footnotetext{
*Psicoanalista SPI-IPA, Università degli Studi di Parma, Dipartimento di Discipline Umanistiche, Sociali e delle Imprese Culturali, Borgo Carissimi 10, Parma.

E-mail: alessandro.musetti@unipr.it
} 
di dimensione mentale in cui mi sono sentito invitato a entrare nella mia personale esperienza di lettore. Partendo da questo vertice, che definirei interculturale, il lettore è accompagnato in un percorso di deidealizzazione della teoresi psicoanalitica pura e allo stesso tempo di ritrovamento di un sapere psicoanalitico inteso come un tessuto di concetti, pratiche, storie personali e contesti di vita. L'autore, lungi dall'avere mire autocelebrative, parla di sé e dei mondi culturali che ha attraversato per ricordare al lettore che la psicoanalisi non ha sede nella libreria polverosa che arreda il suo studio ma al contrario è un discorso vivo che si va facendo nell'interazione tra diverse comunità culturali di analisti - e in un certo senso anche di pazienti. Una prospettiva di tutto interesse per chiunque abbia a cuore il destino di questa disciplina.

Il volume si compone di dodici capitoli a loro volta suddivisi quattro sezioni, rispettivamente dedicate a Freud, Sullivan e Mitchell, Bion/campo psicoanalitico e, infine, alla psicoanalisi internazionale.

A Freud sono dedicate un centinaio di pagine. Si parte dalla corrispondenza di Freud adolescente con Eduard Silberstein, e con Emil Fluss per arrivare alle lettere alla fidanzata Marta e alla scelta degli studi universitari fino all'autoanalisi. Siamo ben lontani da quelle citazioni ornamentali del nostro Maestro che campeggiano vacue in certi scritti privi di spessore psicoanalitico e che scoraggiano anche il lettore più tenace. Nella prospettiva di Conci - rispetto alla quale mi sento particolarmente sintonico - gli epistolari costituiscono una chiave di accesso fondamentale per comprendere più a fondo l'opera di Freud. La psicoanalisi ha iniziato a prendere corpo proprio in quelle lettere: in modo dialogico, attraverso scambi intersoggettivi che da esterni - già ben prima della corrispondenza Freud/Fliess - sono diventati interni, per poi essere formalizzati in concetti e divenire un'ulteriore occasione di scambio di idee. L'idea di un'influenza reciproca tra le relazioni interpersonali e le relazioni intrapsichiche non è solo un assunto fondamentale condiviso da qualsiasi modello psicoanalitico ma può essere anche inteso in senso riflessivo per ripensare in senso storico e relazionale alla psicoanalisi stessa: ' $[$... ] following Fleck, I could say that we need both a group to work with, and also space to think things through for ourselves' (p. 16).

La seconda parte del volume prende in esame le radici del modello teorico interpersonale e gli sviluppi contemporanei in senso relazionale. Sullivan e Mitchell sono le figure cardine attorno alle quali ruota questa riflessione. E qui si apre l'eterna diatriba tra le metafore 'pulsione' e 'relazione', che Conci attraversa ancora una volta evitando facili slogan e sottolineando che ciò che ha preso una forma compita con il concetto di 'osservazione partecipe' di Sullivan è in qualche modo l'onda lunga di quello che Freud stesso ha iniziato a fare con i suoi pazienti - peraltro, come è noto, già Luciana Nissim in Ma Freud era veramente freudiano? aveva messo a fuoco un Freud analista molto più interattivo di quello che si potrebbe desumere dai suoi testi di teo- 
ria della tecnica. Dall'altra parte, spostandoci nel capitolo successivo, la figura di Mitchell è vista da Conci in linea di continuità con il pensiero di Sullivan: 'I propose to look at Mitchell not only as a post- Sullivanian author, but as the best possible continuatore, as I would say in Italian, of Sullivan's work, that is, as his best follower, meaning the author who at best further articulated and continued his work' (p. 152). Il lavoro inedito S.A. Mitchell (1946-2000) in Italy (capitolo 6) è particolarmente utile dato il vuoto di letteratura sulla recezione del pensiero di Mitchell in Italia. Anche in questo caso la documentazione sulla fitta rete di rapporti personali di Conci con gli autori italiani di riferimento della Svolta relazionale e con Mitchell stesso rende bene l'idea delle condizioni storiche - e in un certo senso politiche - che permettono di contestualizzare le teorie dentro a reti di relazioni: 'my role as Stephen Mitchell's 'Italian ambassador' allowed me to establish a whole series of important contacts with some of the most prominent members of the Italian Psychoanalytic Society' (p. 172).

E veniamo a Bion. La terza parte del volume inizia con un capitolo sul rapporto tra Bion e Rickman che tra esperienza di analisi e scambio epistolare tocca diversi punti salienti: 'how Rickman's scientific contribution influenced Bion's scientific production; how important his relationship to Rickman was in the establishment of his identity as a psychoanalyst; and how crucial Bion's life experience and character were to the nature of his psychoanalytic orientation and legacy' (p. 366). A seguire un capitolo su un complesso confronto tra Bion e Sullivan di cui riporto un passaggio singificativo: 'Bion utilized [the very same tools and multidimensional perspective] to find his personal answer to the same fundamental question that Sullivan had set for himself, by writing Learning from experience [Bion, 1962] - for example, an answer such as the concept of 'alfa function' as the key to and/or the threshold from the inanimate world to the dimension of human experience, that is, that very same experience that we can assimilate, communicate, and utilize for our growth, and thus the function that protects us from psychosis' (p. 374). E, in conclusione, una ricca e molto dettagliata ricostruzione delle origini del concetto del campo analitico. Uno snodo teorico di assoluta rilevanza per la psicoanalisi italiana che grazie alla Bionian Field Theory della Scuola pavese ha guadagnato un posto di primo piano a livello internazionale.

La quarta parte è focalizzata per l'appunto sulla psicoanalisi internazionale con un particolare riguardo per quella italiana e tedesca. Anche qui è preziosa l'esperienza e la narrazione in prima persona dell'autore che permette di avere una visione in medias res. Nello specifico un capitolo è dedicato a Gaetano Benedetti e a Johannes Cremerius e due capitoli raccolgono le interviste a Stefano Bolognini e a Horst Kächele. Tutta questa sezione è arricchita da documenti dell'archivio personale di Conci.

Il libro si conclude con uno scritto autobiografico, I was born in Trento, 
Italy, in the spring of $1955 \ldots$ (pp. 547 e sgg.) che rende conto delle vicissitudini che hanno condotto l'autore a questa imponente opera oltre ad essere a tutti gli effetti un lavoro di storia della psicoanalisi/degli psicoanalisti.

Freud, Sullivan, Mitchell, Bion, and the Multple Voices of International Psychoanalysis è una lettura che non può che fare bene a chiunque sia interessato alla psicoanalisi - e in modo particolare, credo, agli studenti di psicologia, agli specializzandi di psicoterapia e ai candidati del training psicoanalitico - perché permette di mettersi in contatto con una psicoanalisi viva. Una psicoanalisi che ha una storia, e quindi uno sviluppo, che non mira alla purezza e all'onniscienza ma ad estendere la possibilità di essere vivi nella propria umanità: questo è il motore pulsante dietro alla trasposizione più libresca del corpus psicoanalitico che spesso allontana ancora prima di essere conosciuto. In attesa dell'edizione italiana del volume, che auspico possa arrivare al più presto, raccomando la lettura della versione in inglese edita dall'International Psychoanalytic Book.

Conflitto di interessi: l'autore dichiara che non vi sono potenziali conflitti di interessi.

Approvazione etica e consenso a partecipare: non necessario.

Ricevuto per la pubblicazione: 25 febbraio 2021.

Accettato per la pubblicazione: 7 marzo 2021.

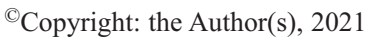

Licensee PAGEPress, Italy

Ricerca Psicoanalitica 2021; XXXII:533

doi:10.4081/rp.2021.533

This article is distributed under the terms of the Creative Commons Attribution Noncommercial License (by-nc 4.0) which permits any noncommercial use, distribution, and reproduction in any medium, provided the original author(s) and source are credited. 